\title{
THE IMPACT OF YOUNG MARRIAGE WITH MARRIAGE DISPENSATION FOR WOMEN AND CHILDREN
}

\author{
Messy Avionica ${ }^{1}$ \\ aviovicamessy@gmail.com
}

\begin{abstract}
Abstrak: Nikah muda menjadi kajian terhangat karena sangat berdampak pada anak dan perempuan. Nikah muda dengan dispensasi nikah merupakan suatu izin pembolehan untuk menikah dengan pasangan di bawah umur, baik salah satu maupun keduanya. Tujuan penelitian ini adalah untuk mengetahui dampak nikah muda dengan dispensasi nikah terhadap anak dan perempuan. Penelitian ini menggunakan pendekatan kualitatif. Pengumpulan data penelitian menggunakan observasi langsung (participant observation) dan wawancara mendalam (depth interview). Hasil penelitian menunjukkan bahwa dampak nikah muda dengan dispensasi nikah terhadap anak dan perempuan, yaitu: kekerasan dalam rumah tangga (KDRT), kerentanan penyakit reproduksi terhadap perempuan, rentan terhadap masalah kehamilan dan janin, kehilangan kesempatan pendidikan, berekspresi dan berkembang, berkreasi, bermain, bergaul dengan teman sebaya, beristirahat dan memanfaatkan waktu luang.
\end{abstract}

Kata kunci: dampak pernikahan dini, perempuan, anak, dispensasi nikah

\section{PENDAHULUAN}

Pernikahan merupakan peristiwa penting dalam kehidupan seseorang. Pernikahan merupakan langkah awal untuk memasuki dunia baru, membentuk keluarga sebagai unit terkecil di satuan masyarakat. Oleh karena itu, diperlukan partisipasi dari keluarga untuk merestui pernikahan tersebut. Amir (2006:35) mengemukakan bahwa dalam literatur fiqh "pernikahan berasal dari dua kata, yaitu: nakaha yang berarti berhimpun dan zawaja yang berarti pasangan”.

Jadi pernikahan dari segi bahasa berarti berhimpunnya dua insan (laki-laki dan perempuan) yang semula terpisah menjadi satu kesatuan yang utuh dan saling melengkapi dalam suatu hubungan yang dihalalkan. Pernikahan yang dilangsungkan akan membawa dampak bagi mereka yang menjalankannya. Di mana, masing-masing pihak akan mempunyai hak dan kewajiban terhadap

\footnotetext{
${ }^{1}$ Penulis merupakan Relawan di Panti Asuhan Ade Irma Suryani Nasution Batusangkar
} 
pasangannya dan memunculkan rasa tolong menolong. Pernikahan merupakan salah satu anjuran agama dengan tujuan mengharap ridha Allah dan merupakan sunah rasul.

Pernikahan dianggap sah apabila dilakukan menurut hukum perkawinan masing-masing agama dan kepercayaan serta tercatat oleh lembaga yang berwenang menurut perundang-undangan yang berlaku. Menurut UndangUndang No. 1 Tahun 1974 pasal 1, “Perkawinan adalah ikatan lahir batin antara seorang pria dengan seorang wanita sebagai seorang suami-istri dengan tujuan membentuk keluarga (rumah-tangga) yang bahagia dan kekal berdasarkan Ketuhanan Yang Maha Esa. Beberapa prinsip untuk menjamin cita-cita luhur perkawinan yang terkandung dalam undang-undang No. 1 tahun 1974 yaitu: asas sukarela, partisipasi keluarga, poligami dibatasi secara ketat, dan kematangan fisik serta mental calon mempelai", (Pasal 6 ayat 3 UU No. 1 tahun 1974)

Jadi perkawinan yang dilakukan atas izin orang tua, dengan mengisi surat izin orang tua (Model N5) dan tanpa paksaan melainkan secara sukarela antara kedua calon mempelai, tanpa ada paksaan dari pihak manapun. Untuk itu diisi surat persetujuan mempelai (Model N3). Salah satu asas yang terkandung dalam undangundang No. 1 tahun 1974 adalah kematangan fisik dan mental kedua calon mempelai. Kematangan yang dimaksud ialah calon suami istri harus telah matang jasmani dan rohani untuk melangsungkan perkawinan. Agar memenuhi tujuan luhur perkawinan yaitu: membentuk keluarga sakinah, mawaddah warrahmah dan mendapat keturunan yang baik dan sehat. Oleh karena itu, harus dicegah perkawinan di bawah umur.

Perkawinan itu sendiri memiliki hubungan erat dengan masalah kependudukan. Menurut Husein, Pernikahan di usia muda yaitu "Pernikahan yang berlangsung antara laki-laki dan perempuan yang beluum baligh yaitu di bawah usia 15 tahun menurut mayoritas ahli fiqh dan di bawah 17 atau 18 tahun menurut $\mathrm{Abu}$ Hanifah", (2001:68). Batas umur yang lebih rendah bagi wanita untuk menikah akan mengakibatkan laju kelahiran yang lebih tinggi, (Habiburrahman, 14 April 2012). Pasal 15 Kompilasi Hukum Islam serta pasal 7 ayat 1 Undang-undang 
Nomor 1 tahun 1974 menyatakan bahwa, "Perkawinan hanya diijinkan jika pihak pria sudah berumur sembilan belas tahun dan pihak perempuan berusia enam belas tahun", (Pasal 29 KUHP).

Kedewasaan dalam hal fisik dan rohani dalam perkawinan adalah merupakan dasar untuk mencapai tujuan dan cita-cita dari perkawinan, walaupun demikian masih banyak juga anggota masyarakat kita yang kurang memperhatikan atau menyadarinya sehingga masih banyaknya masyarakat yang melangsungkan perkawinan di usia muda. Hal ini disebabkan adanya pengaruh lingkungan dan perkembangan sosial yang tidak memadai.

Fenomena di lapangan menunjukkan bahwa beberapa dari perkawinan yang telah dilakukan dengan menggunakan dispensasi nikah baik yang terdaftar maupun yang tidak terdaftar (nikah sirri) memiliki dampak negatif baik terhadap perempuan maupun anak dalam status hubungan pernikahan yang terjadi. Dispensasi nikah banyak diurus bagi pasangan nikah muda yang di bawah umur, namun sudah dalam kondisi hamil yang mengharuskan mereka menikah dengan dalih mendapatkan hak pengakuan atas anak yang dikandungnya.

Hasil observasi peneliti di lapangan ditemukan 5 pasangan yang menikah di usia muda dengan berbagai problematika rumah tangga yang mereka alami karena masih labilnya emosi dari pasangan muda ini, yang akhirnya akan memberikan dampak negatif terhadap perempuan dan anak hasil dari pernikahan yang terjadi. Bentuk dampak negatif yang terjadi sebagai berikut: sering terjadi percekcokan di rumah tangga pasangan muda pemicu timbulnya kekerasan dalam rumah tangga, meningkatnya angka perceraian karena emosi yang masih labil menjadi pemicu untuk mengajukan gugatan cerai atau talak, meningkatkan angka penelantaran anak dari hasil perkawinan, dan kerentanan penyakit reproduksi terhadap perempuan.

Bagi pasangan menikah muda dengan dispensasi nikah disebabkan hanya untuk mendapatkan legalitas pernikahan dan pengakuan atas anak dalam kandungannya, tidak berlandaskan rasa kasih dan sayang untuk mencapai keluarga yang sakinah, mawaddah warrahamah. Selain itu, Menurut Abu Al-Ghifari (2004:40) pernikahan di usia muda juga disebabkan oleh beberapa faktor 
diantaranya: 1) Faktor ekonomi, 2) Pendidikan, 3) Faktor orang tua, 4) Media massa, 5) Sosial budaya dan 6) Pergaulan bebas. Namun, pergaulan bebas yang dianut anak muda zaman sekarang menjadi faktor utama penyebab banyaknya pasangan muda yang belum siap baik secara fisik maupun mental untuk memikul beban tanggung jawab yang belum patut mereka tanggung untuk membentuk keluarga sendiri.

Dilihat dari berbagai faktor di atas yang dapat mendorong terjadinya perkawinan usia muda, dalam penelitian ini penulis bertujuan untuk mendeskripsikan berbagai dampak dispensasi nikah terhadap anak dan perempuan. Selanjutnya, data yang ada menjadi dasar untuk melakukan berbagai intervensi komprehensif yang akan membantu korban dispensasi nikah dalam menjalani kehidupan yang lebih layak.

\section{METODE PENELITIAN}

Rumusan masalah dalam penelitian ini adalah "Apa saja dampak nikah muda dengan dispensasi nikah terhadap anak dan perempuan?”. Tujuan penelitian ini adalah: 1) Agar temuan penelitian ini dapat diterbitkan di jurnal ilmiah; 2) Untuk menambah ilmu dan wawasan khususnya bagi Peneliti tentang dampak nikah muda dengan dispensasi nikah terhadap anak dan perempuan dan solusi mengatasinya; dan 3) Memberikan manfaat bagi pembaca dalam membantu individu korban nikah muda dengan dispensasi nikah dalam menjalani kehidupan yang lebih layak.

Penelitian ini menggunakan pendekatan kualitatif dengan tujuan untuk menggambarkan tentang dampak dispensasi nikah terhadap anak dan perempuan di Jorong Piliang Lima Kaum Tanah Datar. Padahal anak dan perempuan merupakan aset penting suatu negara yang harus dilindungi. Hal ini merupakan fenomena yang menarik untuk diteliti mengingat potensinya yang tinggi tersebut.

Informan ditentukan dengan teknik purpossive sampling. Dalam penelitian ini yang menjadi pertimbangan peneliti adalah bahwa pasangan menikah muda dengan dispensasi nikah baik yang terdaftar maupun yang tidak terdaftar (nikah sirri). Penelitian dilakukan pada 26 Juli 2017 sampai 26 Agustus 2017. Data 
diperoleh dengan melakukan observasi langsung (participant observation), dan wawancara mendalam (depth interview).

Untuk menjamin kualitas keabsahan data peneliti melakukan wawancara secara langsung kepada sumber data, tidak ada wawancara yang diwakilkan kepada orang lain. Peneliti juga melakukan verifikasi data jika terdapat data yang kurang jelas. Pembacaan teori juga peneliti lakukan selama proses penelitian berlangsung untuk menjaga keabsahan data. Teknis analisis data dilakukan dengan analisis model Mailis Huberman. Abdul Halim Hanafi (2015) menjelaskan bahwa analisis model Mailis Huberman digunakan untuk mendapatkan data yang valid dan jenuh. Dengan langkah mereduksi data, mendisplay data, memverifikasi data dan menyimpulkan data.

\section{HASIL PENELITIAN}

Berdasarkan hasil observasi dan wawancara di lapangan pada 26 Juli 2017, ditemukan bahwa ada 5 pasangan muda yang menikah dengan dispensasi nikah baik yang terdaftar maupun yang tidak terdaftar (nikah sirri). Dari hasil observasi diperoleh data bahwa 5 pasangan muda yang menikah dengan dispensasi nikah menunjukkan perilaku negatif seperti: mudah stress, tempramen, emosional dan bersikap lari dari kenyataan. Perilaku negatif yang ditunjukkan pasangan muda ini memberikan dampak yang sangat besar baik bagi perempuan maupun bagi anak hasil dari perkawinan tersebut. Karena dalam hubungan pernikahan perempuan dan anaklah yang sangat rentan menjadi korban baik kekerasan dalam rumah tangga maupun dampak lainnya.

Dispensasi nikah hanya menjadi sekedar penutup aib/malu yang juga didukung oleh keluarga dan lingkungan di mana korban nikah muda dengan dispensasi nikah ini tinggal. Individu yang menjadi korban nikah muda dengan dispensasi nikah cenderung mengalamiketegangan emosi, mengalami frustasi dan bersikap tidak realistis dengan lari dari kenyataan di mana ditemukan salah satu pasangan yang tidak menerima kondisi dirinya yang sudah menjadi ayah dan ibu di usia muda. Akibatnya anak tidak mendapatkan kasih sayang yang utuh dari orang 
tua kandungnya, karena anak lebih banyak menghabiskan waktu dengan anggota keluarga lainnya, seperti anak di asuh oleh nenek, atau saudara ibu yang lainnya.

Peneliti melakukan wawancara mendalam dengan 5 pasangan muda yang menikah dengan dispensasi nikah di Jorong Piliang. Kondisi nikah muda dengan dispensasi nikah ini terjadi karena dua hal yaitu: pasangan nikah muda karena hamil di luar nikah dan ketakutan orang tua anaknya akan berzina setelah menstruasi pertama dikarenakan pergaulan bebas. Nikah muda dengan dispensasi nikah ini ada yang terdaftar dan ada yang tidak terdaftar (nikah sirri). Berdasarkan hasil wawancara dengan kelima pasangan muda yang menikah dengan dispensasi nikah di Jorong Piliang, dapat dipahami bahwa nikah bagi mereka tidak berlandaskan rasa sukarela dan kasih sayang, melainkan karena terpaksa menikah disebabkan sudah hamil di luar nikah dan keluarga ingin anak yang akan dilahirkan mempunyai legalitas dan pengakuan (untuk menutup aib/malu keluarga).

Karena, menurut mereka lebih baik menikah dari pada melahirkan anak tanpa status pernikahan untuk menutupi aib/malu keluarga.Meskipun menikah dalam keadaan hamil yang mereka butuhkan hanya sekedar pengakuan atas status pernikahan dan anak yang akan dilahirkannya. Hal itu didorong oleh status pernikahan yang menjadi penentu posisi dan kedudukan mereka di suatu lingkungan. Mereka menganggap jika hamil luar nikah dan melahirkan tanpa status pernikahan akan meninggalkan aib/malu yang jauh lebih berat bagi diri dan keluarganya. Hal ini juga akan menjadi penghambat bagi mereka dalam menjalin hubungan sosial yang baik dengan lingkungan dan adanya perasaan tidak dihargai oleh lingkungan di mana mereka berada. Mereka merasa tidak berarti ketika lingkungan bersikap cuek dan mengabaikan keberadaan mereka. Namun, lingkungan yang peduli dan menaruh perhatian serta simpati sangat mendorong mereka untuk menjalani kehidupan yang jauh lebih baik. Karena, kehidupan masa lalu tidak menjadi penghalang bagi kehidupan masa depan jika individu tersebut memiliki keinginan dan kesungguhan untuk berubah menjadi lebih baik.

Berdasarkan observasi, dan wawancara yang peneliti lakukan, dampak nikah muda dengan dispensasi nikah lebih banyak dirasakan kaum perempuan dibanding 
laki-laki. Banyak perempuan yang mengalami kekerasan dalam rumah tangga. Kekerasan yang terjadi tidak hanya mengakibatkan kerusakan secara fisik, juga kerusakan secara psikis. Beban mental yang dialami perempuan usia muda dengan tanggung jawab sebagai seorang ibu yang belum masanya, mengakibatkan berbagai gangguan, seperti: pendarahan pada saat melahirkan karena belum matangnya alat repoduksi, bahkan mengakibatkan kematian, karena melahirkan di usia muda. Fisik yang belum matang membuat ibu muda mengalami berbagai gangguan selama masa kehamilan, seperti: bayi lahir kurang gizi, kurang berat dan gangguan lainnya. Sedangkan kondisi psikis yang belum matang, di mana emosi yang masih labil, membuat ibu muda banyak yang belum siap untuk menjadi seorang ibu. Sehingga banyak terjadi kasus aborsi yang membahayakan kondisi ibu dan janin. Pasangan nikah muda juga akan kehilangan kesempatan untuk mendapatkan pendidikan sesuai dengan usianya. Karena di Indonesia tidak membolehkan siswa-siswinya yang berstatus menikah. Sehingga akan menghambat mereka dalam mengembangkan potensinya dan mereka cenderung akan menarik diri dari lingkungan.

Selain itu, dampak yang akan dirasakan oleh anak yang dilahirkan dari pernikahan dengan kasus tersebut ialah anak merasa minder dan tidak diterima oleh lingkungan karena pandangan lingkungan yang membedakan mereka ketika berinteraksi. Hal ini akan menghambat anak dalam proses penyesuian diri dan mengembangkan potensi yang dimilikinya. Albert Bandura salah seorang tokoh psikologi behavioral dalam Prayitno mengemukakan bahwa, "Manusia adalah makhluk reaktif yang tingkah lakunya dikontrol oleh faktor-faktor dari luar. Tingkah laku dipelajari individu ketika berinteraksi dengan lingkungan, melalui hukum-hukum belajar: pembiasaan klasik, pembiasaan operan dan peniruan”, (2005:71). Dengan demikian dapat dipahami bahwa individu melalui pengalaman mengembangkan pola-pola kebutuhan yang mengarahkannya kepada pola tingkah laku tertentu. Bandura juga mengemukakan mengenai teori belajar sosial, bahwa anak belajar dari mengamati (observasional learning). Melalui pengamatan dan proses peniruan seorang anak akan memperoleh informasi dan perilaku baru. Individu yang pernah menyaksikan dan bahkan menjadi korban suatu kejadian, 
kemudian hari akan berpeluang lebih besar untuk menjadi pelaku. Salah satunya dalam kasus nikah muda, anak yang menjadi korban nikah muda berpeluang lebih besar untuk bersikap sama seperti apa yang pernah dialaminya ketika membentuk suatu keluarga baru setelah dewasa. Sehingga, proses penyesuaian diri anak akan mengalami masalah karena trauma yang pernah dialaminya.

Bagi pasangan nikah muda dengan dispensai nikah, status pernikahan merupakan suatu hal yang penting. Karena, menurut mereka jika tidak ada status pernikahan maka akan jauh lebih menyulitkan dan memalukan mereka ketika berada dil lingkungan sosial. Karena dengan kondisi tersebut lingkungan cenderung mengucilkan mereka dan mengabaikan keberadaan mereka. Sehingga akan menjadi beban yang jauh lebih berat bagi mereka terutama bagi anak dan perempuan untuk mendapatkan kehidupan yang jauh lebih baik kedepannya. Status dan pengakuan akan keberadaan menjadi penentu posisi dan kedudukan mereka di suatu lingkungan. Mereka menganggap jika menikah dalam kondisi hamilpun maka mereka diakui di lingkungan dan mampu menjalin hubungan sosial yang baik dengan lingkungan dan adanya perasaan dihargai oleh lingkungan di mana mereka berada. Mereka merasa tidak berarti ketika lingkungan bersikap cuek dan mengabaikan keberadaan mereka. Namun, lingkungan yang peduli dan menaruh perhatian serta simpati sangat mendorong mereka untuk mendapatkan kehidupan yang lebih baik, seperti: lingkungan yang menyediakan kesempatan bagi mereka untuk berinteraksi dan bersosialisasi, baik melalui kursus-kursus yang mampu meningkatkan kehidupan mereka kedepannya.

Jadi, dapat diartikan bahwa pengakuan status pernikahan merupakan suatu usaha yang dilakukan oleh pasangan nikah muda dengan dispensasi nikah untuk menghadapi berbagai tuntutan, baik dari dalam diri maupun dari lingkungan, sehingga mereka mendapatkan hubungan yang serasi dan harmonis dengan orang lain maupun lingkungannya. Setiap pasangan nikah muda mengalami berbagai dampak yang berbeda-beda. Hal ini dikarenakan perbedaan sudut pandang dan perbedaan karakter dari masing-masing individu tersebut. 
Nikah muda merupakan suatu hal yang subjektif bagi setiap individu, karena setiap individu memiliki persepsi dan pandangan yang berbeda mengenai nikah muda. Dari lima pasangan nikah muda dengan dispensasi nikah di Jorong Piliang, yang menjadi subjek penelitian ini memiliki latar belakang yang berbeda-beda, diantaranya: orang tua bercerai, kurangnya perhatian orang tua, salah satu orang tua meninggal dan hak asuh diambil oleh pihak lain, minimnya ekonomi dan rendahnya taraf pendidikan. Jadi, dari kelima pasangan nikah muda dengan dispensasi nikahyang menjadi subjek penelitian memiliki latar belakang yang berbeda-beda. Sikap dan reaksi yang mereka munculkan dalam menyikapi kondisinya juga berbeda-beda. Hal itulah yang menimbulkan dampak yang berbeda juga terhadap perkembangan psikologis mereka ke depannya.

Dampak yang dialami pasangan nikah muda dengan dispensasi nikah di atas diantaranya: kasus AY (14 th) di mana minimnya ekonomi membuat AY dipaksa menikah oleh keluarga di usia belia, demi meningkatkan taraf ekonomi. Tuntutan dari keluarga membuat AY kehilangan berbagai kesempatan baik kesempatan untuk melanjutkan pendidikan, bergaul dengan teman sebaya dan memanfaatkan waktu luang. Karena, waktu AY lebih banyak disita untuk mengurus suami dan rumah tangganya. Orang tua yang seharusnya memberikan tanggung jawab untuk pemenuhan kebutuhan AY malah menjadikan AY sebagai korban demi tercukupinya kebutuhan ekonomi mereka.

Rendahnya taraf pendidikan pasangan muda dan orang tua pasangan nikah muda membuat minimnya pengetahuan akan bahaya dan dampak dari nikah muda tersebut. Bagi mereka, setelah anak gadisnya menikah maka lepaslah beban tanggung jawab mereka sebagai orang tua. Di mana beban itu akan beralih kepada suaminya nanti. Namun, sangat disayangkan ketika pasangan muda ini mengalami berbagai dampak negatif dari pernikahan yang mereka jalani disebabkan kurangnya informasi tersebut. Padahal anak dan perempuan merupakan aset negara terpenting yang harus dilindungi. Seperti kasus MK (15 th 8 bl), bagi MK dan keluarga sangatlah memalukan rasnaya jika setelah menstruasi pertama anak belum mendapatkan pasangan. MK salah satu siswa putus sekolah di kelas $3 \mathrm{SD}$, menurut 
orang tua MK sekolah cukup agar bisa membaca dan berhitung saja, karena waktu akan lebih bermanfaat jika dipakai bekerja untuk menghasilkan uang. MK menjadi salah satu korban keegoisan karena rendahnya taraf pendidikan dan pengetahuan orang tua. Oleh sebab itu perlu kranya diberikan penyuluhan atau pemberian informasi oleh pihak terkait seperti pemerintah setempat tentang dampak dan bahaya nikah muda. Dampak yang dialami MK dari pernikahannya selain kehilangan kesempatan pendidikan, kehilangan kesempatan untuk berekspresi dan berkembang, kehilangan kesempatan untuk berkreasi, bermain, bergaul dengan teman sebaya, beristirahat dan memanfaatkan waktu luang. MK juga mengalami masalah pada kehamilan pertamanya di usia muda, di mana MK mengalami pendarahan hebat karena belum matangnya alat repoduski MK, sehingga MK harus kehilangan buah hatinya di usia muda.

Berbeda dengan kasus AF (15 th) di mana orang tua bercerai. Perceraian orang tua memberikan trauma mendalam bagi AF, sehingga AF melakukan pelarian dan terjebak pergaulan bebas yang mengakibatkan AF hamil di luar nikah dan terpaksa menikah dengan dispensasi nikah. Pernikahan yang tanpa dilandasai rasa cinta dan kesukarelaan, membuat AF semakin terpuruk dengan kondisinya. AF mengalami tekanan emosional dan depresi. Karena AF tidak menemukan kebahagiaan dari pernikahannya. Suami AF yang masih sama-sama berusia muda lebih banyak menghabiskan waktu dengan hura-hura bersama teman-temannya. Sedangkan AF yang sedang hamil terpaksa menanggung beban rumah tangganya sendiri tanpa ada tempat berbagi. AF bahkan nekat menghabisi diri sendiri dan janin dalam kandungan beruntung AF dapat diselamatkan dan melahirkan bayi dengan kondisi kurang sempurna, disebabkan semasa hamil AF seringkali menerima perlakuan kasar dari suaminya, baik berupa tamparan, tendangan bahkan sundutan rokok di beberapa tubuh AF.

Orang tua merupakan pelindung utama bagi anak. Namun, kondisi perekonomian membuat orang tua terlalu sibuk bekerja sehingga anak terabaikan dan kurang perhatian. Hal ini menyebabkan anak mencari perhatian di luar rumah. Pelarian ini banyak yang mengakibatkan anak salah gaul dan tidak tepat dalam 
memilih teman. Seperti kasus TA (15 th 5 bl), TA lebih banyak menghabiskan waktu di luar rumah karena jarangnya orang tua di rumah dan tidak terkontrolnya pergaulan TA karena orang tua lebih banyak menghabiskan waktu untuk bekerja mencukupi kebutuhan rumah tangga. TA putus sekolah setamat SD, dua kali TA keluar masuk SMP dan terpaksa berhenti sekolah karena di DO (drop out). Hal ini disebabkan pergaulan TA yang tidak sesuai lagi. TA terpengaruh lingkungan karena kurangnya perhatian orang tua. TA terpaksa menikah di usia muda karena hamil di luar nikah. Dampak utama yang dirasakan TA tekanan batin karena tidak merasakan indahnya pernikahan. Perlakuan tidak wajar dari suami yang sama-sama berusia muda, seperti: TA menjadi tulang punggung keluarga dalam kondisi hamil, sedangkan suaminya setiap pulang minta uang untuk berjudi, mabuk-mabukkan, dan main perempuan. Jika tidak ada apa yang diinginkannya, maka TA menjadi sasaran kemarahannya, jambakan, hardikan dan bahkan suaminya pernah menduduki perut TA yang sedang hamil besar, karena TA tidak memberikan uang sesuai keinginnannya. Selain kekerasan dalam rumah tangga yang dialaminya, TA juga mengalami penyakit reproduksi akibat suaminya yang senang main perempuan di luar sana.

Berbeda dengan DA (15 th 9 bl) di mana salah satu orang tua meninggal (Ibu) dan hak asuh diambil oleh pihak lain yaitu nenek. DA doasuh oleh neneknya smenejak usia 6 tahun. Pada saat itu Ibu DA meninggal dunia karena sakit dan Ayahnya pergi meninggalkan DA. Semenjak itu tanggung jawab membesarkan DA diambil alih oleh neneknya. Pola asuh yang diterima DA dari neneknya bersifat pengabaian. Di mana semenjak kecil DA sudah terbiasa untuk bermain sepuas hati, pendidikan tidak terlalu penting, kalau mau sekolah ya sekolah kalau tidak ya terserah. Hingga akhirnya DA menemukan kesenangan di luar rumah dengan teman-teman yang kurang tepat, sehingga DA mengalami nasib terpaksa menikah di usia muda karena telanjur hamil. Kehamilan DA tidak membuatnya jera dan merubah kondisinya, perangai DA semakin menjadi-jadi, sehingga suaminya menjadi kesal dan meninggalkan DA dengan kondisi single parent. DA harus berjuang sendiri melahirkan bayinya tanpa didampingi suami dan keluarga lainnya. 
Sekarang DA harus menghidupi dan mencukupi kebutuhan diri dan anaknya dengan berusaha sendiri.

Biasanya pernikahan muda dilakukan oleh pasangan yang rata-rata berumur antara 16-20 tahun. Padahal pernikahan yang ideal untuk perempuan adalah 21-25 tahun sementara laki-laki 25-28 tahun. Karena di usia itu organ reproduksi perempuan secara psikologis sudah berkembang dengan baik dan kuat serta siap untuk melahirkan keturunan dan secara fisikpun sudah matang. Sementara laki-laki pada usia itu kondisi psikis dan fisiknya sangat kuat, hingga mampu menopang kehidupan keluarga untuk melindungi baik secara psikis emosional, ekonomi dan sosial.

Secara umum tidak ada seorangpun yang menginginkan perkawinannya berakhir dengan suatu perceraian, namun demikian sering kali lingkungan yang berbeda, serta perbedaan-perbedaan yang lain sifatnya pribadi mengakibatkan perkawinan tidak bisa dipertahankan keutuhannya. Disamping hal tersebut sering pula tujuan perkawinan tidak dapat terlaksana sesuai dengan cita-cita yang diimpikan sewaktu mereka belum melangsungkan perkawinan sehingga mengakibatkan timbulnya ketegangan-ketegangan sampai pada permusuhan sehingga keutuhan rumah tangga (perkawinan) tidak dapat dipertahankan lagi. Maka untuk mempertahankan suatu prkawinan agar perkawinan tersebut bisa kekal dan bahagia diperlukan persiapan-persiapan yang sangat matang dari kedua calon mempelai baik fisik maupun mental, sehingga mereka menjadi suami istri dengan mudah mendapatkan suatu bentuk persesuaian-persesuaian pendapat dalam mencapai tujuan yang dicita-citakan dalam suatu perkawinan.

Dapat disimpulkan bahwa minimal ada beberapa dampak problematika dispensasi nikah terhadap anak dan perempuan yaitu: Kekerasan dalam rumah tangga (KDRT), kesehatan dan kematangan mental.

1. Kekerasan dalam rumah tangga (KDRT)

Keterbatasan dan ketidakmatangan untuk berumah tangga menyebabkan sering terjadinya cekcok dan petengkaran antara suami istri yang masih belia. Perempuan belia yang sudah menyandang status sebagai istri dan ibu 
sangat rawan menjadi korban dan sasaran kekerasan dalam rumah tangga. Sedangkan laki-laki belia yang sudah mengemban tanggung jawab sebagai seorang ayah, suami dan kepala keluarga cenderung menjadi pelaku kekerasan dalam rumah tangga. Hal ini disebabkan, karena ketidakmatangan secara emosional kedua pasangan muda ini. Mereka masih belum bisa mengontrol emosi dan terlalu dini mengemban tanggung jawab yang belum mestinya mereka tanggung.

2. Kerentanan penyakit reproduksi terhadap perempuan (kanker serviks dan penyakit seksual menular lainnya)

Perempuan yang menikah di bawah usia 20 tahun 58, 5\% lebih rentan terkena penyakit kanker serviks. Disebabkan karena organ reproduksi yang belum siap atau matang untuk melakukan fungsi repsoduksi, rahim yang belum kuat untuk menampung janin, akan beresiko terhadap bahaya pendarahan dan kerusakan organ yang bahkan berujung kematian, cenderung melakukan aborsi yang sering disertai komplikasi dan kematian.

3. Rentan terhadap masalah kehamilan dan janin

Ibu yang menikah muda mengalami kekurangan pengetahuan tentang gizi bagi ibu hamil, sehingga dapat mempengaruhi pertumbuhan dan perkembangan janin. Keadaan perempuan usia muda yang mengandung, melahirkan dan mengurus anak, akan memeberikan beban psikologis, sehingga dapat mempengaruhi petumbuhan dan perkembangan jiwa anak yang dikandungnya.

4. Kehilangan kesempatan pendidikan

Pernikahan usia muda menyebabkan anak kehilangan kesempatan utnuk memperoleh pendidikan. Karena, sistim pendidikan Indonesia tidak ada yang membolehkan siswa-siswinya untuk mengikuti pembelajaran dengan status sudah menikah.

5. Kehilangan kesempatan untuk berekspresi dan berkembang, kehilangan kesempatan untuk berkreasi, bermain, bergaul dengan teman sebaya, beristirahat dan memanfaatkan waktu luang 
Pernikahan usia muda menuntut anak lebih dewasa sebelum waktunya. Mereka diharuskan mengemban tanggung jawab yang semestinya belum mereka tanggung. Hal ini akan menyebabkan terhalangnya anak berekspresi atau berpikir sesuai usianya, karena tuntutan sebagai suami/istri dan sebaagai ayah/ibu. Mereka akan kehilangan masa remajanya, kehilangan waktu untuk berkumpul dengan teman sebaya, karena bertanggung jawab terhadap keluarga. Faktanya mereka yang menikah usia muda belum bisa mengurus keluarga dan anak, bahkan mengurus diri sendiri belum bisa.

Upaya yang dilakukan untuk mengatasi dampak yang ditimbulkan oleh pernikahan dini dapat merujuk kepada lima langkah yang penting, yaitu:

1. Melakukan sosialisasi undang-undang perkawinan yang diharmonisasikan dengan undang-undang perlindungan anak.

2. Keluarga harus mengajarkan dan menanamkan nilai-nilai yang baik sejak dini kepada anak, serta memberikan bimbingan, perlindungan dan pengawasan agar anak tidak terjerumus dalam pergaulan bebas.

3. Sekolah bekerjasama dengan organisasi sosial untuk memberikan penyuluhan dan bimbingan mengenai risiko menikah muda, pendidikan seks semenjak dini, konseling kesehatan reproduksi remja dan bahaya seks pra nikah.

4. Memberikan anak kesempatan memperoleh pendidikan dengan mengupayakan pendidikan dasar 12 tahun.

5. Memberikan penyuluhan kepada pasangan nikah muda tentang makna hak dan kewajiban suami/istri dalam rumah tangga.

\section{PENUTUP}

Dari hasil penelitian dan pembahasan yang telah diuraikan sebelumnya, maka dapat disimpulkan bahwa fenomena nikah muda dengan dispensasi nikah mempunyai berbagai dampak. Dampak negatif nikah muda dengan dispensasi nikah bagi perempuan jauh lebih besar dibanding laki-laki. Dampak-dampak ini akan berpengaruh pada kualitas keluarga yang dihasilkan, ditinjau dari sisi 
ketidaksiapan fisik ibu dalam mengandung dan melahirkan bayi maupun kesiapan psikis dalam menghadapi persoalan sosialatau ekonomi rumah tangga, dan membina rumah tangga serta menjadi orang tua yang bertanggung jawab. Pernikahan usia muda dnegan dispensasi nikah sangat berpengaruh pada kehidupan anak dan remaja sebagai generasi penerus bangsa dalam memberikan kontribusi dan melaksanakan peranannya di tengah masyarakat. Dampak problematika dispensasi nikah bagi anak dan perempuan, yaitu: Kekerasan dalam rumah tangga (KDRT), kerentanan penyakit reproduksi terhadap perempuan (kanker serviks dan penyakit seksual menular lainnya), rentan terhadap masalah kehamilan dan janin, kehilangan kesempatan pendidikan, kehilangan kesempatan untuk berekspresi dan berkembang, kehilangan kesempatan untuk berkreasi, bermain, bergaul dengan teman sebaya, beristirahat dan memanfaatkan waktu luang.

Berdasarkan hasil penelitian di lapangan, perlu kiranya pihak terkait memberikan perhatian yang lebih khusus. Maka dapat diajukan beberapa saran yang dapat bermanfaat dalam menangani kasus nikah muda dengan dispensasi nikah, yaitu:

\section{Guru Bimbingan dan Konseling}

Diharapkan kepada Guru Bimbingan dan Konseling untuk memberikan penyuluhan atau bimbingan mengenai permasalahan sosial tentang program terkait dengan bidang hidup berkeluarga, terutama risiko menikah muda melalui pendidikan seks dini, konseling kesehatan reproduksi remaja dan bahaya seks pra nikah.

2. Pasangan Nikah Muda

Diharapkan kepada pasangan nikah muda sebaiknya diperhitungkan terlebih dahulu resiko yang akan dihadapi, seperti: perceraian pasangan nikah muda dengan dispensasi nikah agar mereka dapat mengoptimalkan potensi dengan mengembangkan skill (keterampilan) yang dimiliki dengan pembinaan, pelatihan dan mengikuti kursus-kursus untuk menunjang kehidupannya yang lebih layak. 
3. Orang Tua

Diharapkan kepada orang tua agar lebih memantau perkembangan dan pergaulan anak-anaknya khususnya remaja usia labil.

4. Peneliti

Untuk peneliti selanjutnya dapat ditindak lanjuti dengan penelitian deskripsi solusi pengentasan masalah nikah muda di kalangan remaja.

5. Pihak Keluarga

Bagi pihak keluarga, disarankan melakukan kontrol dan contoh teladan yang baik bagi korban dispensasi nikah agar mereka dapat lebih optimis dalam menjalani kehidupan. Oleh karena itu, semua pihak terkait harus memikirkan hal terbaik menyangkut kehidupan anak.

6. Pihak terkait

Kepada Pemerintah setempat untuk memberikan penyuluhanpenyuluhan tentang pentingnya pendidikan terhadap masyarakat.

Kepada Lembaga Kemasyarakatan agar menghimbau kepada masyarakat tentang dampak dan bahaya perkawinan usia muda dan sebisa mungkin menghilangkan budaya kawin muda. 


\section{DAFTAR PUSTAKA}

Amir Syarifuddin. 2006. Hukum Perkawinan Islam di Indonesia antara Fiqh Munakahat dan UU Perkawinan. Jakarta: Prenada Media

Badan Pusat Statistik (BPS) dan ORC Macro Survei Demografi dan Kesehatan Indonesia 2002-2003, Calverton, ORC Macro, Maryland USA. 2003.

Undang-undang perkawinan No. 1 tahun 1974

Fatchiah E. Kertamuda. 2009. Konseling Pernikahan Untuk Keluarga Indonesia. Salemba Humanika.

Habiburrahman. 14 April 2012. Permasalahan hukum perkawinana dalam praktek Pengadilan Agama. Rakernas

HM. Bayu Mahyudi. 1 Juni 2006. Resiko Pernikahan Dini. Sriwijaya Pos

Husein, muhammad. 2006. Fiqh Perempuan. Yogyakarta: LKIS

Nurwati N, Review: Hasil Studi Tentang Perkawinan Dan Perceraian Pada Masyarakat Jawa Barat. Jurnal Kependudukan Padjadjaran, Bandung, 2003:5(2): 59-67

Shofiyah Faridatus. Fenomena Dispensasi Perkawinan di Pengadilan Agama Blitar. Skripsi. UIN Maliki: Malang

Ni'ami Uswatun. Dispensasi Nikah di Bawah Umur. Tesis. UIN Maulana Malik Ibrahim: Malang

Prayitno. 2005. Konseling Pancawaskita, Padang: UNP Press

Sarwono, S. W. (2001). Psikologi Remaja. Jakarta: Rajawali Pers

Seminar Kementerian Agama Republik Indonesia. 26 Desember 2012. mengenai Strategi Mengatasi Perkawinana di Bawah Umur dan Perkawinan Tidak Dicatat. Jakarta

Suparman. Eman 2001. Upaya Mencegah Kebiasaan Kawin Muda Di Kalangan Remaja Di Pedesaan. 